\title{
Affective engagement in academic reading: What EFL student teachers reveal
}

\author{
Made Frida Yulia ${ }^{1}$, Gunadi Harry Sulistyo ${ }^{2}$, Bambang Yudi Cahyono ${ }^{3}$ \\ ${ }^{1}$ English Language Education Study Program, Universitas Sanata Dharma, Indonesia \\ ${ }^{1,2,3}$ Graduate Program in English Language Teaching, Universitas Negeri Malang, Indonesia
}

\begin{abstract}
Article Info
Article history:

Received Mar 30, 2020

Revised Jun 26, 2020

Accepted Aug 4, 2020

\section{Keywords:}

Academic reading

Affective engagement

EFL

Reading engagement

ABSTRACT

Academic reading is an inescapable task in higher education. Due to its importance for study success, students are required to maintain their academic reading engagement. With engagement, they would be enabled to persevere and be more spirited in their reading efforts. However, not all students perceive academic reading positively, particularly in EFL learning environment where English reading is seen as something daunting. Academic reading engagement is essentially determined by a number of dimensions, one of which is affective dimension. This research aims to portray the affective dimension of the academic reading engagement among student teachers of English as a Foreign Language (EFL) in a teacher-training university in Indonesia. Eight EFL student teachers were selected from three classes of an English content course which required a lot of academic reading. These student teachers were interviewed using a semi-structured guide. The results show that many EFL student teachers' efforts in coping with course-related reading materials were externally driven. They showed low liking for learning, demonstrated little enthusiasm, interest, enjoyment, and confidence in relation to academic reading. Also, they did not always understand the values of academic reading and text relevance for their development as teachers.
\end{abstract}

This is an open access article under the CC BY-SA license.

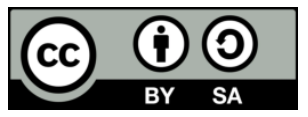

\section{Corresponding Author:}

Made Frida Yulia,

Graduate Program in English Language Teaching,

Universitas Negeri Malang,

Jl. Semarang no. 5, Sumbersari, Lowokwaru, Malang 65145, Indonesia.

Email: frida@usd.ac.id

\section{INTRODUCTION}

Reading is a critical means to access knowledge and information in academic life [1]. Such a critical skill to access knowledge and information is highly necessary in higher education [2-4]. Higher education students are confronted with various resources which are mostly presented in English. Besides, they are expected to make an analysis and synthesis of texts with varying levels of difficulties [4, 5]. Therefore, to succeed academically, English reading skills should be fostered so that students can develop personally and hence succeed academically [4, 6-9].

Unfortunately, although reading is crucial, research has found that many students dislike it [10], let alone reading in a foreign language. Students of various disciplines in the second year of university level were found to be not enthusiastic about reading. A similar phenomenon also occurs in other education levels [11-13]. Bektas-Cetinkaya [2] reveals a contradictory practice in which students admit their enjoyment for reading but in reality, spend insufficient time on the activity. These findings show that reading is not a favorite academic activity among the students $[2,14]$. They seem to be unprepared to confront the reading 
demands imposed on them [4]. Nevertheless, they acknowledge the significance of English reading for their study success but prefer reading in their native language [2]. Likewise, in addition to insufficient time spent on academic reading, Yulia, Ena, and Prabandari [15] unveil the absence of willingness among English teacher candidates too, in carrying out their responsibilities to read academic materials.

It is undeniable that academic reading can be arduous. The nature of the texts, the level of language sophistication, and the complexity of the concepts of the disciplines [6, 7, 16-18] are some of the reasons. Moreover, further issues enhance the complication, i.e. the limited background knowledge in the related area, the insufficient reading practice required of the students, as well as the inadequate ways to cope with the given reading tasks [19]. Research has discovered that students at higher education level have not been adequately successful in coping with academic reading tasks $[3,9,19,20]$. They have a substandard level of academic comprehension [3] and low level of readiness in dealing with academic reading tasks [4, 9]. In consequence, they frequently complain about the reading demands required of them. They tend to avoid rigorous text processing and employ inappropriate strategies when their anxiety level is heightened [21], thus giving up reading easily.

Reading engagement is said to be crucial to enhance reading success [22, 23]. Such engagement is useful for students to deal with academic reading in any levels of education because it will enable them to boost their spirit, spend longer time, and make more efforts in the act of reading. Reading engagement enables them to interact meaningfully with a text in terms of social aspect, behaviors, cognition and affect $[23,24]$. One of the aspects of reading engagement which concerns students' emotions in diverse classrooms contexts [25] is affective dimension. It has to do with what drives students to read and participate in various activities around reading [17]. It means to say that affective reading engagement deals with students' motivation to read as well as emotional reactions that they feel while doing the reading tasks, such as interest, boredom, happiness, sadness, and anxiety [26].

Motivation for reading may be extrinsic $[11,27,28]$ or intrinsic $[8,13,28]$. Intrinsic motivation occurs when they are empowered to read because of the enjoyment and fulfillment reaped from the activity [8, 13]. Meanwhile, extrinsic motivation occurs when L2 reading is done because they want to obtain something from reading, such as to complete assignments and to receive good grades [11, 27]. Reading motivation may predominantly be affected by teachers, followed by home and peers [29].

The research gap suggests investigating reading engagement in academic materials among student teachers of English as a Foreign Language (EFL), since extensive research on the area has been conducted mainly in L1 settings and ESL settings from elementary to high school levels (e.g. [6, 14, 27, 30-32]). Research on academic reading engagement in the tertiary level has not sufficiently explored university students in EFL settings. Some existing studies are [2, 19, 20, 23]. On top of that, little is known about the academic reading engagement of university students who are prepared to be English teachers, whereby reading in English is mandatory throughout their academic and working lives.

This article is limited to addressing this question: How is EFL student teachers' affective engagement in academic reading described? As stated earlier, affective dimension is one aspect of reading engagement which has to do with one's motivation and emotional reactions that accompany the process of academic reading [26]. The choice of EFL setting was unearthed from the synthesis of previous research findings. The results of the study would provide a portrayal of the EFL student teachers' affective engagement in academic reading and inform EFL teacher educators in their efforts to promote such engagement in their student teachers, specifically for the design of more rewarding content courses.

\section{RESEARCH METHOD}

This study employed a qualitative design, phenomenology, in its attempt to capture the diversity of engagement experience [33,34]. Eight research subjects who were student teachers from an EFL teacher training university in Yogyakarta, Indonesia, participated in the study. They were taken among eligible subjects who had plenty of experiences in learning content courses related to English Language Education major which used English as a medium of instruction and which required them to do a lot of academic reading in English. At the time the research was conducted, there was only one content course that met the selection criteria. The accessible course was a linguistic course offered in the sixth semester, namely Sociolinguistics, which had three parallel classes. From these classes, subjects were taken to represent two different groups of reading engagement shown during the teaching-learning processes. They were selected carefully based on the teacher educators' evaluation on the student teachers' engagement in the class and the researchers' observations. Group 1 consisted of four EFL student teachers who showed high engagement, while Group 2 consisted of four students who showed low engagement. A semi-structured interview was used to obtain data portraying the affective dimension of the EFL student teachers' engagement in reading academic materials. The discussion was initially concerned with the content course they were taking that 
semester, but it was also extended to elicit their relevant experiences in other content courses as appropriate. Triangulation was conducted by using multiple sources of data. The researchers compared the responses across subjects and across time in follow up interviews.

\title{
3. RESULTS AND DISCUSSION
}

This section presents and discusses the findings obtained from the data. It describes the reading motivation and emotional reactions which the EFL student teachers felt in dealing with academic reading tasks, such as their likes and dislikes, interest, enthusiasm, enjoyment, and confidence in their undertaking. In addition, it also discusses their perception on the values of academic reading and text relevance. As mentioned earlier, there were two groups consisting of four participants each. The members of Group 1 were A, B, C, and D. Meanwhile, E, F, G, and H were the members of Group 2. Of these, A, B, F, and G were male, whereas $C, D, E$, and $G$ were female. They were all from the sixth semester.

The first immediate emotional reactions that the EFL student teachers demonstrated varied from neutral, neutral to negative, and negative. The neutral emotional reactions occurred among EFL students' teachers who showed high engagement (Group 1). They seemed to have been aware of the required reading tasks at the tertiary level. It indicated that these student teachers belonged to a small number of students who had been prepared for the reading demands at university level which were required of them [4, 9]. Rather, they did not perceive it as a burden, viewed it as something habitual, and showed commitment to academic life requirements [35]. This point was apparent in the statement of one of the student teachers in Group 1.

\begin{abstract}
"My reaction is just neutral. It is something ordinary and habitual. I have been used to reading demands since I was in the first semester. It is something normal in college life. Even though there were times, not frequently, when there were multiple assignments and I somehow felt the reading was just giving more load on me." (D, Group 1)
\end{abstract}

This excerpt supported $[36,37]$ in that it implied that they had engagement which enabled them to persevere and exhibit higher dedication in their study. Despite any barriers which may sometimes be in their way, they kept on reading and were not so much affected by any external factors.

However, the neutral to negative reactions happened when there were a high number of assignments from multiple courses and these assignments slightly distracted their concentration for course reading, as A, $\mathrm{B}$, and D admitted. Consequently, they would prioritize the urgent assignment first. Moreover, mood was put forward by $\mathrm{B}, \mathrm{C}$, and $\mathrm{G}$ as an influential factor in reacting towards academic reading. It was evident in the following student teachers' statements.

"My reactions depend on my condition at that moment. When I feel lazy and I am not in a good mood, I am reluctant to read. Not every day though, but it occasionally happens. I feel not so spirited to read." (C, Group 1)

"It depends very much on my mood. When my mood is good, I will take it positively, I will do it, but when my mood is not good, I am lazy to do it. I am bored with doing the reading over and over. So, my reactions will be either neutral or negative. Other than being not in a good mood, usually negative reactions occur when I am not fit because of too many works to do. Rarely do I feel excited when asked to read." (G, Group 2)

Meanwhile, those showing negative emotional reactions mostly belonged to Group 2, which demonstrated low reading engagement. E, F, and $\mathrm{H}$ acknowledged that they were fed up with being asked to do course reading over and over, and they were reluctant to do it. Some of the evidences were as follows.

"I am so reluctant knowing or hearing that I am assigned to read. Why should I read?? The teacher rarely explains. She just instructs us to read, discuss it with our group, explain our own parts to other group members and we should listen to each other. I am very confused whom to trust. In a word, reading course materials is a burden for me. I am disinclined to do it." (F, Group 2)

"When there are many pages to read in class within limited amount of time, I am hesitant to do it. Usually I grumble. I am bored when I am assigned to do course reading. No fun at all. I feel it is just an additional burden." (H, Group 2) 
These excerpts denoted the complaints E, F, and $\mathrm{H}$ made on the instructed reading assignments, as [4] had also unveiled. They were unhappy with other parties, such as the teacher educators' ways of teaching, the learning activities, and/or the reading materials. They did not have awareness that reading academic materials is a compulsory activity to uptake knowledge in higher education level [1] and the key to academic life success [4, 6-9]. Sadly, none of the EFL student teachers exhibited positive emotional reactions towards course reading, which was an unavoidable activity during their study. The finding was consistent with previous studies [10-13].

Subsequently, the EFL student teachers were asked to reflect on their own practices in terms of what made them read or not read course materials. From their responses it was obvious that internal factors as well as external factors played a role in their participation. Concerning the internal factors which influenced their willingness to do academic reading, A, C, D, and G mentioned interest and curiosity in the topics, B, D, and $\mathrm{F}$ mentioned physical fitness, and $\mathrm{B}, \mathrm{D}, \mathrm{G}$, and $\mathrm{H}$ mentioned mood. Their mood was influenced by the teacher educators' ways of teaching, the amount of required reading, and the types of content courses. For instance, B and D revealed that they were not in favor of education courses because they did not intend to become teachers.

As for the external factors which affect their academic reading participation, B, C, E, F, G, and $\mathrm{H}$ claimed that teacher educators' ways of teaching were mostly influential. Meanwhile, A, D, E, and H stated that the existence of post-reading assignments was another influential factor. Furthermore, E and F argued that text factor had an influence on their willingness to read. They revealed that they would read if the texts were interesting and not complicated. It supported Wickramaarachchi [5] that simplification of vocabulary and syntax of a reading text of a foreign cultural origin would be of great help to improve the comprehension of L2 learners whose academic comprehension was low or insufficient. Additionally, they reasoned that the reading texts should have good layout and illustrations to interest them. This statement implied that they were not dedicated readers who would keep on reading no matter whether the text was interesting or not [29]. Furthermore, B, D, and G brought out the issue of environment as an influential factor. Environment referred to the physical surroundings where they did the course reading, or people with whom they got along. When some EFL student teachers, like F, G, and H, befriended people who did not like reading or studying, they would be affected. Or else, when they became a wanted person to share their understanding with their peers, like B and D, they would also be more encouraged to share their reading activities with their friends to make them more knowledgeable [11,27]. The peer factor was in agreement with [29] and [38], claiming that motivation may be affected by peers and others. Up to this point, it was apparent that the EFL student teachers' involvement in academic reading activities was more extrinsically motivated [11, 27, 28].

All of the participants agreed that the existence of assignments which must be done after course reading predominantly moved them to read. The compulsory post-reading tasks somehow pushed them to read. Surprisingly, all the EFL student teachers, except F, admitted that they liked the post-reading activities which the teacher educators designed. Nevertheless, some of them had preference over types of post-reading activities even though they did not have unanimous opinion on the issues. For instance, A, B, and C disliked mind mapping because in their opinion mind mapping was very personal and depended on individuals' understanding and logic. It would not be easy to follow other people's way of thinking if they did not share the logic. These student teachers preferred completing activity sheet, containing gap-fills or comprehension questions, which they thought was simple and easy to understand, presentation and roundtable discussion. The last two activities were preferred by EFL student teachers who disliked writing and favored an oral activity instead, such as B and C.

The involvement of many EFL student teachers in the post-reading activities was influenced by the degree to which they liked the activities. However, to some of the EFL student teachers who were autonomous, like $\mathrm{B}, \mathrm{C}$, and $\mathrm{D}$, their activity preferences did not have a large effect on their reading participation. They could take charge of their own learning and to them their responsibilities were the priorities [39]. As the following student teachers reported:

"Although I have preference over the post-reading activities, it does not affect my involvement in them. I am aware I have responsibilities to finish the assignments." (B, Group 1)

"My involvement is not so much influenced by the type of post-reading activities employed. For instance, I do not like presentation, which takes longer time to prepare, and I am not comfortable speaking in front of people. What is more, when I have to work with people who are not pleasing, it makes the task harder for me. But I still do my best despite my dislike." (D, Group 1) 
Additionally, $\mathrm{H}$ avowed that her involvement in the post-reading activities was also determined by the physical fitness, the partners with whom to work, and the need to avoid failing the course.

The EFL student teachers in Group 2 liked doing post-reading activities as long as they were done in groups. They argued that they could share burden and responsibilities as well as learn from each other [40]. It was evident from the following expressions:

"I like activities which are done in group whereby I can have discussions in them, completing worksheets or creating digital content. I also do not mind with presentations, and mind mapping. I prefer interactions whereby I can listen first to others presenting and ask questions." (F, Group 2)

$\mathrm{F}$ and $\mathrm{G}$ also touched on the issues of mutual enrichment that they may obtain from discussions. The evidence was shown in the following excerpt:

"Yes, I like the activities which should be done after reading. They are intended to make me understand what I read. Whatever the activities are, I do not mind as long as they are done in groups. Discussion with other people may enrich understanding." (G, Group 2)

When they were asked about their willingness to find additional sources for enrichment other than the prescribed course books, all the EFL student teachers acknowledged that they relied mostly on the prescribed reading texts, except for $\mathrm{E}$ and $\mathrm{F}$ who would attempt to find internet sources which were simpler, shorter, and more comprehensible when the texts were too difficult, even though they were not citable sources. Their purpose was mainly to substitute the prescribed texts, not to complement them. Only one EFL student teacher in Group 1, C, claimed that she was willing to find additional sources because she needed them to successfully complete her assignments, which were mostly papers. It indicated that the additional references she found were not to substitute the prescribed reading texts, but to complement them. Additionally, B and D stated that they would endeavor to find more sources, be they journals or books, only when the courses interested them or the topics aroused their curiosity. It implied that their search for additional sources was intrinsically-oriented, which had something to do with fulfillment [8, 13].

When the EFL student teachers were invited to evaluate the interestingness of the course materials, they, except B, E, and F, responded that the topics they learned in the content course were objectively interesting because those topics were closer to their daily life. Furthermore, they had ambivalent opinions on their enthusiasm in learning the course materials. Their enthusiasm may be somewhat affected by their lack of passion to become a teacher, as A, B, D, F, and $\mathrm{H}$ unveiled. F and $\mathrm{H}$ stated that they were in EFL teacher education because their family wanted them to be there. Whereas A, B, and D, although they did not want to be teachers, realized that English is a stepping stone to gain a better life and, thus, they liked learning English and wanted to use it later for professions other than teaching. In general, all of the reasons for the presence and absence of enthusiasm were driven by external forces. These forces stemmed from the types of content courses, the topics, the difficulty level of the reading materials, and the teacher's teaching style. The last one was in line with [29], claiming that motivation may be affected by teachers and others. Of eight people, only $\mathrm{C}$ was highly eager to become an English teacher; hence, she was enthusiastic to learn all courses provided by the EFL teacher training university.

"Yes, I believe they are important for me. Since I want to become a teacher, knowing the implications of the topics for teaching will be helpful for my career preparation. Besides, the content of the course is also beneficial, such as appropriate way of speaking, status, etc. They are vital for daily life." (C, Group 1)

Surprisingly, the majority of the EFL student teachers, except A, B, and F, believed that the course materials they learned were important for them, either as a language user or a future language teacher, although those belonging to Group 2 were not able to outline the direct benefits they felt, as seen from the following statements:

"I think they are important for me as a language user and a future language teacher. I can apply them even when I am not in Java, such as the topics about language features, choosing variety or codes, style context register, function of speech, politeness. The factor that prevents me from reading is laziness, although I am interested in the topics and I am aware that they are important for me. My mindset now is I am not going to work hard if I do not feel it is necessary. When I can still handle it in a relaxed manner, why make it 
difficult? I do not see any urgency for me to read course materials myself, because I can still manage through listening to others' explanation." (G, Group 2)

Enjoyment while doing course reading was not found among EFL student teachers who showed low engagement. They felt compelled to perform the activity because they did not have free will to do it. The finding lent support to [15]. Their drive to academic reading was extrinsically-oriented; i.e. only for the sake of assignments $[11,27]$. They were overburdened by the reading tasks. By contrast, the EFL student teachers who showed high engagement felt enjoyment when they could understand and relate the topics to their life context. For instance, when learning about code switching, the issue of Anak Jaksel dialect came to their mind and then was connected. It suggested that the new knowledge they learned could be related to their previous knowledge to yield a more meaningful learning [41].

The EFL student teachers were also not confident in undertaking academic reading. They all perceived it as a difficult task, although they had been in the third year of university. There were some reasons which they put forward and they all strengthened the findings of previous studies. First, it was about the reading materials which did not arouse their interest [7], as B, D, and E revealed. Second, it was about the level of difficulties of the reading materials in terms of the complexity of the concepts and the language as well as the lack of background knowledge [6, 16-19], as C, F, G, and $\mathrm{H}$ acknowledged. Third, it was about the amount of reading which was required of them [4, 19], which E, F, G, and H reported as too much. They oftentimes had assignments from various content courses all at once, which made them feel overwhelmed and used it as an excuse to avoid reading. Fourth, the reading was viewed as tedious because of the absence of free will [15], such as what happened to F. Fifth, their dislike for reading itself, even in the native language [10], as A, F, and $\mathrm{G}$ experienced, prevented them from liking academic reading in English. Their reading process was painstaking in which repetition over and over should be done to gain understanding [21].

Concerning the issues of relevance of the course materials, EFL student teachers who showed high engagement could mention the relevance of the topics to their being a language user or a future language teacher, as follows:

"Yes, they are relevant to my context, as a language user or a future teacher. For example, about social distance between student and teacher, the language use will be different when their relations are closer." (A, Group 1)

"In my opinion, the course materials I learn so far are all relevant. What is discussed in sociolinguistics is about society's language, although not directly related to Java, but it can be universally applied to other places or contexts. Similarly, with other linguistics courses I can immediately see the relevance." (D, Group 1)

Unfortunately, the EFL student teachers who showed low engagement could not see the relevance of the materials in linguistic classes to their own context. What they could immediately see was the contribution of the contents of education courses to their future career. The statements of $\mathrm{F}$ and $\mathrm{H}$ lent support to this issue.

"In the context of sociolinguistic course, I have not seen the relevance of the course, the implication it has for me or my future. What my friends answered in class when being asked about the implication of studying one particular topic was just very general and tended to be the same between one and another." (F, Group 2)

"I have not seen any relevance from sociolinguistic topics I learn to my life and also from other linguistics classes. What I can see is the direct benefits from education courses, to equip me to become a teacher." (H, Group 2)

\section{CONCLUSION}

The study uncovered that the EFL student teachers' affective reading engagement in academic materials was not positive. It was mentioned earlier that lack of preparedness to cope with the academic reading demands on tertiary education causes students to complain frequently about it. In this study only a few of the EFL student teachers demonstrated preparedness for the required academic reading which they should undertake in university life. This small number of student teachers divulged their learning autonomy and could sustain their persistence and learning commitment. Despite negative emotional reactions towards 
academic reading which most EFL student teachers showed, they responded more positively to the postreading tasks. This may be due to the formats and/or the variety of the tasks. Their motivation to read was extrinsically-oriented and their engagement was driven by external factors, such as teacher educators, peers and reading texts. Their liking for reading and learning content courses was low, and so were their enthusiasm, interest, confidence, and enjoyment in academic reading activities. Most of them perceived academic reading as a burden and were not able to see the relevance of the content materials they learnt to their context as a language user and/or a future language teacher.

The study shed some light into the issues of academic reading engagement. It provided a portrait of the affective engagement of the EFL student teachers in reading academic materials. The findings would inform EFL teacher educators in their efforts to promote the affective reading engagement of their student teachers, and specifically to design more rewarding content classes. Further research is needed to link affective dimension of academic reading engagement to reading proficiency and/or academic achievement, and may address teacher educators' efforts to enhance student teachers' reading motivation and positive emotional reactions towards academic reading in content classes.

\section{ACKNOWLEDGMENT}

The research was supported by Indonesia Endowment Fund for Education Lembaga Pengelola Dana Pendidikan (LPDP) in registration number 20161141081847.

\section{REFERENCES}

[1] J. Zheng and N. Kang, "An investigation on English reading strategy use in major-related materials among native and foreign language learners," Journal of Language Teaching and Research, vol. 5, no. 2, pp. 283-290, 2014.

[2] Y. Bektas-Cetinkaya, "Reading experiences of nonnative-English-speaking preservice English teachers: A Turkish case," TESOL Journal, vol. 3, no. 1, pp. 17-32, 2012.

[3] A. M. Bhooth, H. Azman, and K. Ismail, "Investigating the reading practices of the EFL Yemeni students using the Learning by Design Framework," TESOL Journal, vol. 6, no. 3, pp. 413-603, 2015.

[4] M-Y. Shen, "Developing EFL learners' academic reading skills - Diagnostic and needs analysis through action research,” The Asian EFL Journal Quarterly, vol. 17, no. 1, pp. 117-137, 2015.

[5] T. I. Wickramaarachchi, "'I can't read this! It's so difficult!" - The impact of the difficulty of texts on ESL reading comprehension," The Asian EFL Journal Professional Teaching Articles, vol. 102, pp. 17-28, 2017.

[6] O. Akarsu and L. Harputlu, "Perceptions of EFL students toward academic reading," The Reading Matrix, vol. 14, no. 1, pp. 61-75, 2014.

[7] S. M. Jafari and N. Shokrpour, "EAP students' reading motivation of English academic expository texts: A mixed methods design," International Journal of Linguistics, vol. 4, no. 4, pp. 372-392, 2012.

[8] S. Neugebauer, "Stable or situated understandings of adolescent reading engagement across readers and raters," The Journal of Educational Research, vol. 109, no. 4, pp. 391-404, 2016.

[9] G. H. Sulistyo, "Assessing non-English department students' mastery of academic content area reading," Jurnal Ilmu Pendidikan, vol. 19, no. 1, pp. 37-49, 2013.

[10] A. J. Applegate, M. D. Applegate, M. A. Mercantini, C. M. McGeehan, J. B. Cobb, J. R. Deboy, et al., "The Peter Effect revisited: Reading habits and attitudes of college students," Literacy Research and Instruction, vol. 53, no. 3, pp. 188-204, 2014.

[11] S. Abrar-Ul-Hassan, "A study of the motivational patterns of learners of English for academic and professional purposes," TESOL Journal, vol. 5, no. 1, pp. 32-56, 2014.

[12] J. T. Guthrie and A. Wigfield, "Engagement and motivation in reading," in Handbook of reading research, vol. 3, M. L. Kamil and P.B. Mosenthal, Eds. Mahwah, NJ: Erlbaum, pp. 403-422, 2000.

[13] V. Vaknin-Nusbaum, E. Nevo, S. Brande, and L. Gambrell, "Developmental aspects of reading motivation and reading achievement among second grade low achievers and typical readers," Journal of Research in Reading, vol. 41, no. 3, pp. 438-454, 2018.

[14] M. S. Protacio, "A case study exploring the reading engagement of middle grades English learners," Research in Middle Level Education Online, vol. 40, no. 3, pp. 1-17, 2017.

[15] M. F. Yulia, O. T. Ena, and C. S. Prabandari, "ELESP_students' reading habit and the suitability of content-area reading materials," in ELTeaM international conference proceedings, vol. 2, Sudarsono, U. Salam, Istiqamah, and A. Marwan, Eds. Pontianak, Indonesia: ELTeaM, pp. 97-111, 2014.

[16] E. Swanson, J. Wanzek, S. Vaughn, A-M. Fall, G. Roberts, C. Hall, et al., "Middle school reading comprehension and content learning intervention for below-average readers," Reading and Writing Quarterly, vol. 33, no. 1, pp. 37-53, 2017.

[17] A. Taboada, D. Townsend, and M. J. Boynton, "Mediating effects of reading engagement on the reading comprehension of early adolescent English language learners," Reading and Writing Quarterly, vol. 29, no. 4, pp. 309-332, 2013.

[18] C. Tarchi, "Fostering reading comprehension of expository texts through the activation of readers' prior knowledge and inference-making skills," International Journal of Educational Research, vol. 72, pp. 80-88, 2015. 
[19] E. Hirano, “'I read, I don’t understand': Refugees coping with academic reading,” ELT Journal, vol. 69, no. 2, pp. 178-187, 2015.

[20] K T-C, Chen, "An exploratory study of NNES graduate students' reading comprehension of English journal articles," Reading in a Foreign Language, vol. 29, no. 1, pp. 20-35, 2017.

[21] M. Roustaei, "Reading anxiety and its relation to reading proficiency, reading strategy, and gender: The case of Iranian EFL learners," The Asian EFL Journal Professional Teaching Articles, vol. 84, pp. 4-32, 2015.

[22] J-S. Lee, "The relationship between student engagement and academic performance: Is it a myth or reality?" The Journal of Educational Research, vol. 107, no. 3, pp. 177-185, 2014.

[23] P. R. M. A. Rahim and F. Hashim, "Facilitating reading engagement by foregrounding students' voices through epistolary writing: A case study," GEMA Online Journal of Language Studies, vol. 15, no. 1, pp. 57-75, 2015.

[24] J. T. Guthrie, A. Wigfield, and K. C. Perencevich, Motivating reading comprehension: Concept-oriented reading instruction. Mahwah, NJ: Erlbaum, 2004.

[25] J. A. Fredricks, P. C. Blumenfeld, and A. H. Paris, "School engagement: Potential of the concept, state of the evidence," Review of Educational Research, vol. 74, no. 1, pp. 59-109, 2004.

[26] N. J. Unrau and M. Quirk, "Reading motivation and reading engagement: Clarifying commingled conceptions," Reading Psychology, vol. 35, no. 3, pp. 260-284, 2014.

[27] R. Komiyama, "Factors underlying second language reading motivation of adult EAP students," Reading in a Foreign Language, vol. 25, no. 2, pp. 149-169, 2013.

[28] R. M. Ryan and E. L. Deci, "Intrinsic and extrinsic motivations: Classic definitions and new directions," Contemporary Educational Psychology, vol. 25, no. 1, pp. 54-67, 2000.

[29] J. Cambria and J. T. Guthrie, "Motivating and engaging students in reading," The NERA Journal, vol. 46, no. 1, pp. 16-29, 2010.

[30] S. C. Cantrell, J. F. Almasi, M. Rintamaa, J. C. Carter, J. Pennington, and D. M. Buckman, "The impact of supplemental instruction on low-achieving adolescents' reading engagement," The Journal of Educational Research, vol. 107, no. 1, pp. 36-58, 2014.

[31] S. C. Cantrell, J. Pennington, M. Rintamaa, M. Osborne, C. Parker, and M. Rudd, "Supplemental literacy instruction in high school: What students say matters for reading engagement," Reading and Writing Quarterly, vol. 33, no. 1, pp. 54-70, 2017.

[32] R. Zhao and A. Hirvela, "Undergraduate ESL students' engagement in academic reading and writing in learning to write a synthesis paper," Reading in a Foreign Language, vol. 27, no. 2, pp. 219-241, 2015.

[33] E. R. Kahu, "Framing student engagement in higher education," Studies in Higher Education, vol. 38, no. 5, pp. 758-773, 2013.

[34] S. B. Merriam, Qualitative research: A guide to design and implementation. San Francisco: John Wiley \& Sons, Inc., 2009.

[35] P. E. Kahn, "Theorising student engagement in higher Education," British Educational Research Journal, vol. 40, no. 6, pp. 1005-1018, 2014.

[36] J. Pietarinen, T. Soini, and K. Pyhältö, "Students' emotional and cognitive engagement as the determinants of wellbeing and achievement in school," International Journal of Educational Research, vol. 67, pp. 40-51, 2014.

[37] M. Wang and J. Eccles, "Adolescent behavioral, emotional, and cognitive engagement trajectories in school and their differential relations to educational success," Journal of Research on Adolescence, vol. 22, no. 1, pp. 31-39, 2011.

[38] J. Kormos, T. Kiddle, and K. Csizer, "Systems of goals, attitudes, and self-related beliefs in second-languagelearning motivation," Applied Linguistics, vol. 32, no. 5, pp. 495-516, 2011.

[39] S. Borg and S. Al-Busaidi, Learner autonomy: English language teachers' beliefs and practices, 2012. [Online]. Available: http://englishagenda.britishcouncil.org/sites/ec/files/B459\%20ELTRP\%20Report\%20Busaidi_final.pdf

[40] Washington University, Benefits of group work, 2016. [Online]. Available: https://teachingcenter.wustl.edu/resources/active-learning/group-work-in-class/benefits-of-group-work/

[41] J. Hassard, Backup of meaningful learning model, 2003. [Online]. Available: http://www5.csudh.edu/dearhabermas/advorgbk02.htm 